\title{
The prevalence of rheumatic heart disease in northeastern Thailand is declining
}

In this issue of Asian Biomedicine, Chaikitpinyo and colleagues have presented evidence of an almost five-fold decrease in the prevalence of rheumatic heart disease (RHD) in schoolchildren in northeastern Thailand during the 20 years from 1986 to 2006 [1]. Although one might question whether these data represent other parts of Thailand, and while one might further question the epidemiology of RHD in Thailand, the presented data nevertheless correlate with a downtrend of prevalence of RHD in other surveys in Thailand [2-5]. Furthermore, the presented data also correlate with a downtrend of prevalence of RHD in some other developing countries [6]. These data are likely representative of the current status concerning the prevalence of RHD in many developing countries at the beginning of the $21^{\text {st }}$ century [1-6]. The declining prevalence of RHD in Thailand results in a decreased incidence of the heart valve surgery [7] and decreased incidence of stroke [8-9] in many referral centers in Thailand [7-9].

Why is the prevalence of rheumatic heart disease declining in Thailand?

RHD results from acute rheumatic fever (ARF), which can be prevented by timely and adequate antibiotic treatment of group A streptococcal throat infections known as primary prophylaxis [10-13].

The most severe cases of RHD are the result of recurrent attacks of ARF. These recurrent attacks are almost entirely preventable with regular administration of penicillin to patients with a documented history of ARF or evidence of RHD. This secondary prophylaxis is the most cost effective of all public health programmes and has been recommended by the World Health Organization (WHO) and the World Heart Federation (WHF) for over 20 years [13-16]. The recommendations include screening for RHD, registering patients, and providing regular secondary prophylaxis [14].

The decline of the prevalence of ARF and RHD in Thailand can be seen with an improvement in

Correspondence to: Manat Panamonta, Department of Pediatrics, Faculty of Medicine, Khon Kaen University, Khon Kaen 40002, Thailand. E-mail: manat@kku.ac.th living standards and health care services [1] resulting in better identification of cases of RHD, increasing compliance with secondary prophylaxis, and probably decreased acquisition of group A streptococci [1, 13-16].

Future directions in the control of rheumatic heart disease

Despite more than a century of research of ARF and RHD, very little has changed in how we diagnose and control these diseases in clinical practice. Physicians still depend on a clinical diagnosis and appropriate management of the etiologic streptococcal infections and their complications, i.e. ARF and RHD. There are many unresolved questions relating to ARF and RHD, which are being addressed by basic, epidemiological and clinical research, including the development of a group A streptococcal vaccine [13].

As for other infectious diseases, such as smallpox, poliomyelitis, measles, diphtheria, and tetanus, the development of vaccines and implementation of wide immunization programmes has the potential for controlling group A streptococcal infections [17]. Currently, there are group A streptococcal vaccines in very early clinical trials, a suitable preparation for widespread use will not be available for a number of decades. Furthermore, the cost effectiveness and additional contribution of group A streptococcal vaccine over and above the current strategy advocated by the WHO needs further clarification.

In conclusion, physicians and public health authorities need to continue the current conventional methods by implementing this relatively simple and cost effective approach $[13,14,16]$.

\section{References}

1. Chaikitpinyo A, Panamonta M, Wongswadiwat Y, Weraarchakul W, Panamonta O, Panthongviriyakul A, et al. Rheumatic and congenital heart diseases among school children of Khon Kaen, Thailand: declining prevalence of rheumatic heart disease. Asian Biomed. 2014; 8:645-50.

2. Cholkraisuwata E, Buddharaksaa Y, Sayasathidb J. Congenital heart disease in elementary school children in rural Thailand: the role of the trained non- 
cardiologist. Asian Biomed. 2013; 7:287-91.

3. Pongpanich B, Dhanavaravibul S, Limsuwan A. Prevalence of heart disease in school children in Thailand: A preliminary survey at Bang Pa-in. Southeast Asian J Trop Med Pub Hlth. 1976; 7:91-4.

4. Panamonta M, Chaikitpinyo A, Klungboonkrong V, Tantisirin C, Bhuripanyo K. Heart diseases in school children: a preliminary survey in the Khon Kaen municipal area. Srinagarind Hosp Med J. 1986; 1:253-7.

5. Vichitbandha P, Podhipleux P, Prachuabmoh C, Nana A, Kongsamran S, Rungpitarungsi B, et al. Epidemiology of heart disease in school children in rural and urban areas. J Med Assoc Thai. 1981; 64: 1-10.

6. Negi PC, Kanwar A, Chauhan R, Asotra S, Thakur JS, Bhardwaj AK. Epidemiological trends of RF/RHD in school children of Shimla in north India. Indian J Med Res. 2013; 137:1121-7.

7. Chotivatanapong T, Lerdsomboon P, Sungkahapong V. Rheumatic mitral valve repair: experience of 221 cases from Central Chest Institute of Thailand. J Med Assoc Thai. 2012; 95 (Suppl 8):S51-7.

8. Tiamkao S, Sawanyawisuth K, Silaruks S, Kiatchoosakun S, Tatsanavivat P, Chotmongkol V, Klungboonkrong V. Correlation of causes and outcomes in stroke in the young. J Stroke Cerebrovasc Dis. 2013; 22:55-7.

9. Sitthi-Amorn C, Tatsanavivat P, Sawadsitang W, Keoyoo J, Mahawerawat U. Death and stroke rate in chronic rheumatic heart disease. J Med Assoc Thai. 1988; 71:302-9.

10. Panamonta M, Chaikitpinyo A, Auvichayapat N,
Weraarchakul W, Panamonta O, Pantongwiriyakul A. Evolution of valve damage in Sydenham's chorea during recurrence of rheumatic fever. Int J Cardiol. 2007; 119:73-9.

11. Panamonta M, Chaikitpinyo A, Kaplan EL, Pantongwiriyakul A Tassniyom S, Sutra S. The relationship of carditis to the initial attack of Sydenham's chorea. Int J Cardiol. 2004; 94:241-8.

12. Panamonta M, Settasatian N, Kaplan EL, Chaikitpinyo A. Serum cholesterol levels in patients with acute rheumatic fever. Am J Dis Child. 1993; 147:732-6.

13. Carapetis JR. Rheumatic heart disease in developing countries. N Engl J Med. 2007; 357:439-41.

14. WHO expert consultation on rheumatic fever and rheumatic heart disease (2001: Geneva Switzerland). Rheumatic fever and rheumatic heart disease: report of a WHO expert consultation, Geneva, 29 October - 1 November 2001. Geneva: World Health Organization, 2004.

15. McDonald M, Brown A, Noonan S, Carapetis JR. Preventing recurrent rheumatic fever: the role of register based programmes. Heart. 2005; 91:1131-3.

16. WHO Cardiovascular Diseases Unit and principal investigators. WHO programme for the prevention and control of rheumatic fever/rheumatic heart disease in 16 developing countries: report from Phase I (198690). Bull Wld Hlth Organ. 1992; 70:213-8.

17. Panamonta M, Chaikitpinyo A, Lumbiganon $\mathrm{P}$, Panamonta O, Auvichayapat N, Wongswadiwat Y, et al. Historical document of diphtheritic myocarditis from a Northeastern Thailand hospital. Asian Biomed. 2014; 8: 475-84. 